\title{
Fear and irony on Tobacco Road: notes from the Fourth Tobacco International Exhibition and Conference
}

\author{
John Bloom
}

"THE WORLD IS COMING TO TOBACCO COUNTRY!" So proclaimed advertisements in the tobacco trade press touting the Fourth Tobacco International Exhibition and Conference held in Raleigh, North Carolina, from 2-4 June 1992.

It was an opportunity too good to pass up: an invitation, according to Tobacco International, to hear the top brass from Philip Morris, RJ Reynolds, and leading tobacco trade associations talk about "socio-political issues to the year 2000." Inspired by the successful exploits of notable industry watchers such as Luk Joossens in Europe and Alan Blum and Greg Connolly in the United States, I packed my car and headed south towards Raleigh.

It was well worth the long drive. The conference, especially the third day (see box), offered valuable insight into the tobacco industry's hopes and fears, as well as the industry's views of international tobacco control efforts.

Though this "spy mission" may evoke images of elaborate deception, the truth is not so glamorous. I registered under my own name and truthfully stated on the form that I was an "international trade consultant." I relied entirely on anonymity and good luck to evade what turned out to be a serious effort by conference organisers to identify and exclude attendees with ties to health groups.

Two better known health advocates were not so fortunate. Stan Glantz of the University of California at San Francisco was officially disinvited shortly before the conference began, and Alan Blum of Doctors Ought to Care (DOC) was asked to leave the conference during the first day (see p. 50).

I knew none of this when I arrived on the second day. Sitting in the auditorium, I opened the morning Raleigh News and Observer and quickly noted two things: firstly, the headline on the front page, above the masthead, was "Activist Ousted from Tobacco Meeting." Secondly, the conference had misspelled Alan Blum's name as "Bloom" - the same as mine. I casually moved my name tag from the outside of my suit jacket to the inside, where it could be seen but not easily read. I resolved to keep a very, very low profile. Even so, I weathered a few awkward moments at the exhibition when exhibitors asked for my business card. One managed to read my name tag. "Hey, I read about you in the newspaper," he said. I carefully explained about the misspelling of names and my embarrassment at being mistaken for that activist doctor.

There can be no doubt about the concern of conference organisers with security. Attendees were required to walk through a single door into the auditorium so that each name tag could be scrutinised. A prohibition on recording and picture taking was announced repeatedly and strictly enforced by monitors. And, most regrettably, none of the talks on "socio-political issues" were distributed in writing. "I guess they're considered too sensitive," a woman at the registration desk said when I asked why.

Both the conference and the exhibition were surprisingly modest in scope and scale. There were about 316 registrants at the conference, with 100 to 200 in attendance at any given moment. The exhibition, which was held just across a courtyard from the conference, boasted an impressive list of major companies that cater to the tobacco industry (see pp. 51-52). Attendance there too, however, seemed low given the pre-exhibition hype.

Another surprise was that the programme portion of the conference consisted of only a handful of papers each day, with no formal programme beyond noon. Not much for the $\$ 600$ registration fee. The real action, it appeared, was going on in closed meetings, on the social circuit, and on the local golf courses. Closed meeting rooms were reserved for Philip Morris and the Tobacco Merchants' Association, among others, and the conference programme was sprinkled with social events (see figure).

The first day of the conference, which I did not attend, had been devoted primarily to the leaf trade. The second day featured presentations on the latest manufacturing materials, techniques and technologies. The presentations were reminiscent of technical articles that appear every month in the trade press. This is no coincidence; presentations at the conference, such as Monty White's "Some aspects of primary processing and tobacco degradation," already have turned up as articles in Tobacco International.

The third day was a strategic goldmine (box). It featured several of the industry's public affairs elite speaking on the past, present, and future of "attacks" on the 


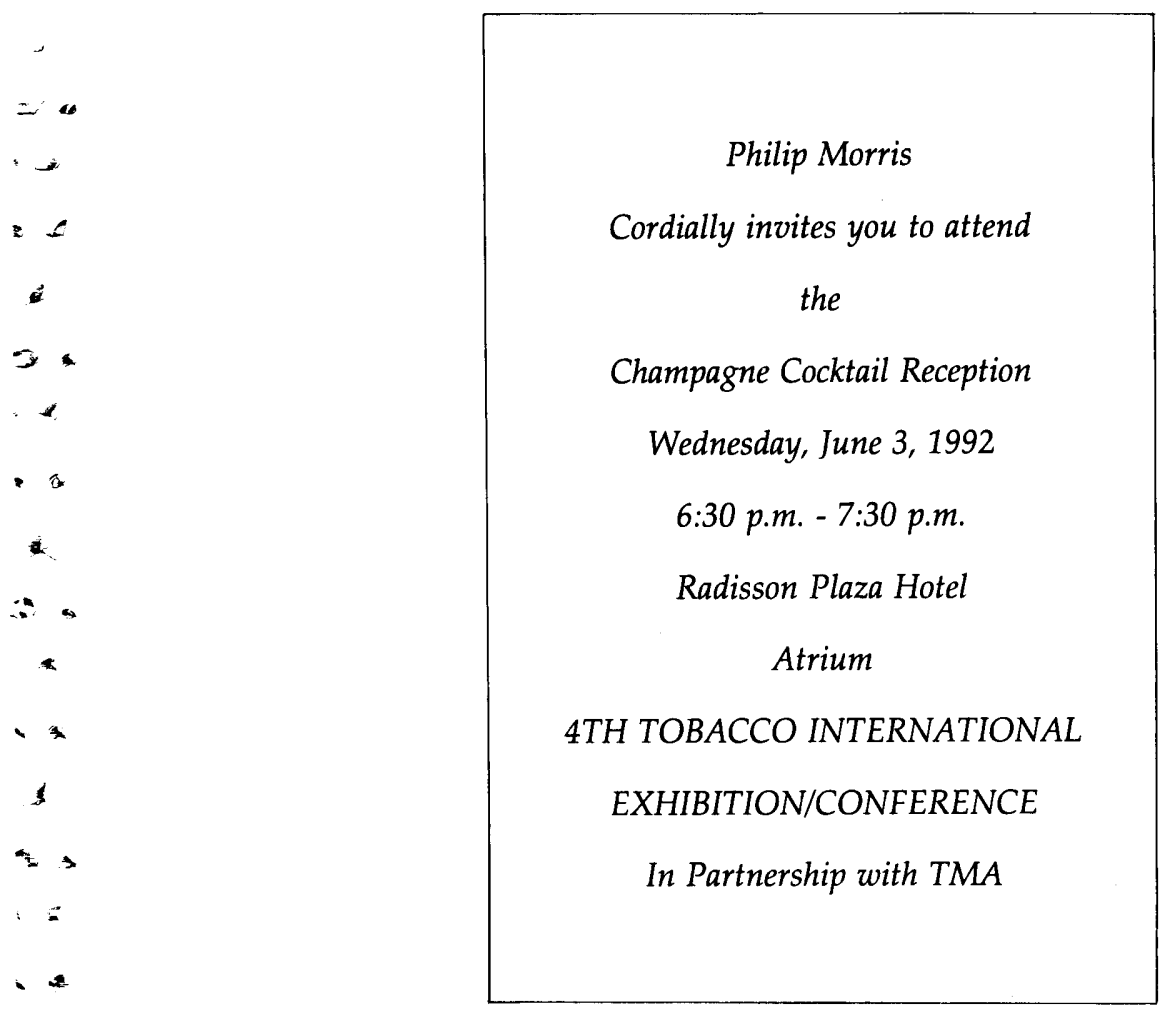

$\leftarrow$

< industry by health groups. Essentially, this was an effort to rally the troops, to provide guidance by putting an industry spin on health issues, and, above all, to reassure everyone that with their assistance, the industry would prevail over its critics and enjoy, in the words of Dale Sisel, president and chief executive officer of RJ Reynolds's Tobacco International, "a bigger and brighter tomorrow."

\section{Ironies abound}

The conference was rich in irony, beginning with the morning headline: "Helms Enters Hospital for Heart Bypass Today." Jesse Helms, tobacco's most powerful and outspoken defender in the US Senate, had been ordered by his doctor to stop smoking in advance of the surgery, the article reported.

There were laughably ironic attempts by an industry with worldwide sales measured in the hundreds of billions of dollars to portray itself as the victim of an "anti-tobacco industry." The company line appeared to be that health lobbyists are greedy opportunists preying on the tobacco industry because doing so has become lucrative. As one speaker put it, "The truth is that the anti-smoking industry is wellfunded and feeds a lot of people."

Finally, there were unexpected ironies in the backgrounds of some of the speakers. Consider, for example, Ron Tully of the Tobacco Documentation Centre in London. Tully gathers intelligence on health groups for the tobacco industry. He came to work for the industry after one stint working at the Christie Hospital and Holt Radium Institute and Paterson Laboratories in Manchester, United Kingdom, Europe's largest cancer treatment employers is the Royal College of Surgeons of Edinburgh. It seemed only fitting that I took and research centre; another of his former copious notes as Tully reported on his experiences as an "industry spy" at the Eighth World Conference on Tobacco or Health in Buenos Aires, Argentina, two months earlier.

Matthew Winokur, director of corporate affairs for Philip Morris International, noted in his credentials listed in the programme that he earned his bachelor's degree in religion. He told those who don't see the connection between religion and his work expanding Philip Morris's overseas cigarette markets, "I guess a common thread is that both religion and tobacco involve acts of faith."

Another speaker, Thomas Griscom, coordinated all communications and strategic planning for Ronald Reagan's White House from 1987 to 1988 . Now he works for the RJ Reynolds Tobacco Company and introduced himself as "Mr Joe Camel." It is his job to orchestrate RJR's response to the uproar caused by the infamous cartoon camel's effect on youth.

\section{Watching them watching us}

The audience showed a keen interest in learning who the "antis" are, how they are funded, and how they network with one another. Ron Tully had special expertise in this area and was anxious to share what he had learned at the world conference in Buenos Aires. He displayed slides of the conference programme, the conference resolutions, promotional materials, and other mementos.

Another speaker, Jacques LaRiviere, vice president of the Canadian Tobacco Manufacturers Council, commented that he was " one of about 12" industry representatives monitoring the 1983 World Conference on Smoking and Health in Winnipeg, Canada. He said he thought that the conference marked the critical turning point when tobacco control leaders agreed that political action, rather than health research, was the top priority. LaRiviere also said that he believed tobacco control leaders had been linked electronically since 1983, long before the advent of the American Cancer Society's GLOBALink computer network in 1990.

Several other speakers, including Matthew Winokur of Philip Morris, also displayed a familiarity with health group dynamics.

\section{Peeking into the industry's anxiety closet}

One of the questions to which I sought answers at the conference was this: When industry executives survey the tobacco control movement, what really scares them? What keeps them awake at night? The answer came in the form of five recurring themes and warnings sounded by the speakers.

\section{FEAR OF FRACTURE AND ISOLATION}

The fear that cigarette manufacturers will find themselves pariahs within the business community came through repeatedly. Indeed, the entire programme seemed designed to draw retailers, farmers, suppliers, and other 
branches of the industry into battles now being waged primarily by manufacturers. This was reflected in the keynote speech by RJR's Dale Sisel: "Joining hands across the industry from farmers to suppliers to the trade." The fear of isolation was reflected at another level by the speakers' consistent efforts to link tobacco issues to other concerns. Thus Thomas Griscom sought to link the "antismokers" to extremism and intolerance of every kind, from attacks on synagogues, book burning, assaults on women wearing fur coats, and discrimination against people with AIDS to the enforcement of "politically correct" thought, racism, and, of course, totalitarianism.

THE GLOBALISATION OF THE TOBACCO CONTROL MOVEMENT

The GLOBALink computer network was mentioned as one symbol of the "coming of age" of the global tobacco control movement. This very journal was mentioned as another such symbol. Ron Tully displayed slides of the latest promotional materials for GLOBALink and Tobacco Control. Tully also presented a slide intended to depict the "inner circle" of the international tobacco control movement. At the top of the circle was the International Union Against Cancer (UICC); the American Cancer Society and the World Health Organisation were at the sides, and the Advocacy Institute was at the bottom. The result of this globalisation, lamented Dale Sisel, is that "never before have we had such intense pressure from the antis. Their message is being spread rapidly across international borders, and the industry has been slow to respond to this increasing pressure."

\section{PUBLIC-PRIVATE PARTNERSHIPS}

Another major concern was the trend towards public-private partnerships in tobacco control such as the American Stop Smoking Intervention Study (ASSIST), the multi-million dollar collaborative project between the US National Cancer Institute and the American Cancer Society. Ron Tully also mentioned California's Proposition 99 funding mechanism as a new development to watch. "I'm sure many of you have heard of the rather problematic advertisements in California," Tully said, referring to California's counter-advertising campaign. US Surgeon General Antonia Novello was singled out for criticism, both for her "attacks on the first amendment" (her criticism of RJR's "Joe Camel" advertising campaign) and for the 1992 Surgeon General's report, which focused for the first time on smoking in Latin America. The report was dubbed by Matthew Winokur "an inappropriate use of US taxpayer money."

ETS, TAXES, AND AD BANS

Speakers seemed to view environmental tobacco smoke (ETS) as the issue on which the
Day 3 agenda for Fourth Tobacco International Exhibition and Conference

Socio-political issues to the year 2000

Introduction

David Michôd, TMA director, president/chief executive officer, Tobacco Exporters International and chairman/chief executive officer, Lane Limited, Tucker, Georgia

Foining hands across the industry - from farmers to suppliers to the trade

Dale Sisel, president and chief executive officer, RJ Reynolds Tobacco Int, Winston-Salem, North Carolina

Tobacco in the context of other industries - taking a look ahead to the year 2000

Thomas Griscom, executive vice president external relations, RJ Reynolds Tobacco Company, Winston-Salem, North Carolina

Anti-tobacco issue overview

Ron Tully, Director of Information Services, Tobacco Documentation Centre, London, United Kingdom

Is free speech disappearing?

David Remes, Esq, Covington and Burling, Washington, DC

What happens after Cipollone: trends in product liability litigation

Walter Cofer, Esq, Shook, Hardy, and Bacon, Kansas City, Missouri

Canada : a bellwether market?

Jacques LaRiviere, vice president, Canadian Tobacco Manufacturers Council, Ottawa, Ontario

\section{Industry strategies}

Introduction

Hideshi Fujishiro, TMA director, general manager, Japan Tobacco Inc, New York, New York

General overview

Moderator: Matt Winokur, director, corporate affairs, Philip Morris International, Inc, Rye Brook, New York

Legal and regulatory status of ETS

Clausen Ely, Esq, Covington and Burling, Washington, DC

Advertising freedom in Canada: the Chabot decision

Barbara B Kacir, Jones, Day, Reavis, and Pogue, Cleveland, Ohio

Countering the EC tobacco advertising ban Manfred Körner, director, Standpunkt, Hamburg, Germany

Winning the Hong Kong tax battle

JP Lee, executive director, Tobacco Institute of Hong Kong Ltd, Hong Kong

Grand Finale Reception/Dinner at Capitol City Club, hosted by GD, Körber, Molins, Sasib, and Schmermund

industry is most vulnerable, although taxation and advertising ranked close behind. Other issues, including litigation, warning labels, and 
regulation of additives, received decidedly less attention and were addressed with a sense of confidence. Matthew Winokur called ETS "the most difficult issue facing the industry," adding that "frankly, if our customers can't use the products we make, we and they have a serious problem." This view echoed similar, if more colourful, comments by Clive Turner of the Asian Tobacco Council, addressing the sixth world tobacco exhibition and symposium, held in Austria in 1990 and attended by Luk Joossens. "Passive smoking," he said, "has offered some anti-smokers almost orgasmic bliss. At last they have a big and almost magic stick with which to beat the industry, and one which they feel will inflict unbearable pain." The industry has powerful allies on advertising and taxation issues, Winokur said. But with ETS, the industry's only allies are smokers, who are not professional advocates.

FEAR OF LOSING

The most gratifying of the recurring themes was that, in the words of Dale Sisel, "the very future of the industry is threatened by increasing anti-smoking activities." Speaker after speaker sounded messages of hope for growth and prosperity for the tobacco market and called the crowd to arms. There was no comment at all from the audience until, at the end of Ron Tully's presentation, a lone voice called out from the back: "We seem to be losing this war."

\section{Lessons on the importance of language}

One of the implicit lessons of every speaker was on the importance of language. The words "health," "disease," "cancer," and "death" were studiously avoided. Industry adversaries were rarely referred to as "health groups" or "doctors," but as "anti-smokers" or simply "antis."

I must confess, however, my disappointment at the limited range of epithets for health advocates used by industry spokespersons at this gathering. My expectations had been raised by quotes from Clive Turner at the industry's 1990 conference in Austria. There, in a single speech, he described those in the tobacco control movement as "natural zealots," "health faddists," "anti-tobacco single-issue fanatics," and "tobacco haters." $\mathrm{He}$ went on to compare health advocates to "locusts... gnawing away at our growers, our distribution, our profitability, and our very future," to beavers "beavering away" at the industry, and to "slavering hounds" savouring tax hikes. "I call them shower adjusters," Turner continued. "They would enjoy adjusting your shower temperature for you if they could get access, just knowing exactly what is right for you - and for all mankind."

Alas, no one at this conference had Turner's flair for metaphor and hyperbole. 